Association for Information Systems AIS Electronic Library (AISeL)

ICIS 1985 Proceedings

International Conference on Information Systems

1985

\title{
Competitive Information Systems in Support of Pricing
}

Cynthia M. Beath

UCLA

Balke Ives

Dartmouth College

Follow this and additional works at: http://aisel.aisnet.org/icis 1985

\section{Recommended Citation}

Beath, Cynthia M. and Ives, Balke, "Competitive Information Systems in Support of Pricing" (1985). ICIS 1985 Proceedings. 21.

http://aisel.aisnet.org/icis1985/21

This material is brought to you by the International Conference on Information Systems (ICIS) at AIS Electronic Library (AISeL). It has been accepted for inclusion in ICIS 1985 Proceedings by an authorized administrator of AIS Electronic Library (AISeL). For more information, please contact elibrary@aisnet.org. 


\title{
Competitive Information Systems in Support of Pricing
}

\author{
Cynthia M. Beath \\ UCLA
}

\author{
Balke Ives
}

\author{
Dartmouth College
}

\begin{abstract}
Considerable attention has recently been paid to the opportunities presented by information systems technology for implementing, or even driving, corporate strategy. But organizations attempting to identify systems that provide competitive advantage are finding the search to be frustrating and often unrewarding. This paper combines two familiar information systems concepts, the Anthony model and information attributes, to produce a framework for identifying one class of competitive information systems, systems in support of product pricing.

For the vast majority of companies operating in imperfect markets, pricing is an information intensive process, in which ambiguous cost projections are balanced with elusive estimates of demand in an attempt to satisfy conflicting stakeholders. As such, pricing presents a rich opportunity to creatively apply information systems technology for competitive advantage. To assist in identifying applications we present a framework to structure the search and a series of working examples that can motivate synergistic discovery.

The framework, shown below, categorizes pricing information systems according to decision type and information attributes. The $\mathrm{Y}$-axis contains the three levels of management decision making proposed by Anthony [1965]; four areas of pricing decision-choosing a pricing strategy, setting the basic price level, determinign the price structure, and the price administration-are mapped into the Anthony model. The X-axis includes categories of information attributes taht information systems are likely to impact. We illustrate the matrix by mapping examples into the cells.

We are hopeful that readers familiar with a particular firms's attributes and competitive environment will find that the examples help stimulate the discovery of new pricing applications. The paper concludes with some thoughts on using the framework. An appendix to the paper presents a "pricing primer" for those unfamiliar with the pricing process and its information requirements.
\end{abstract}




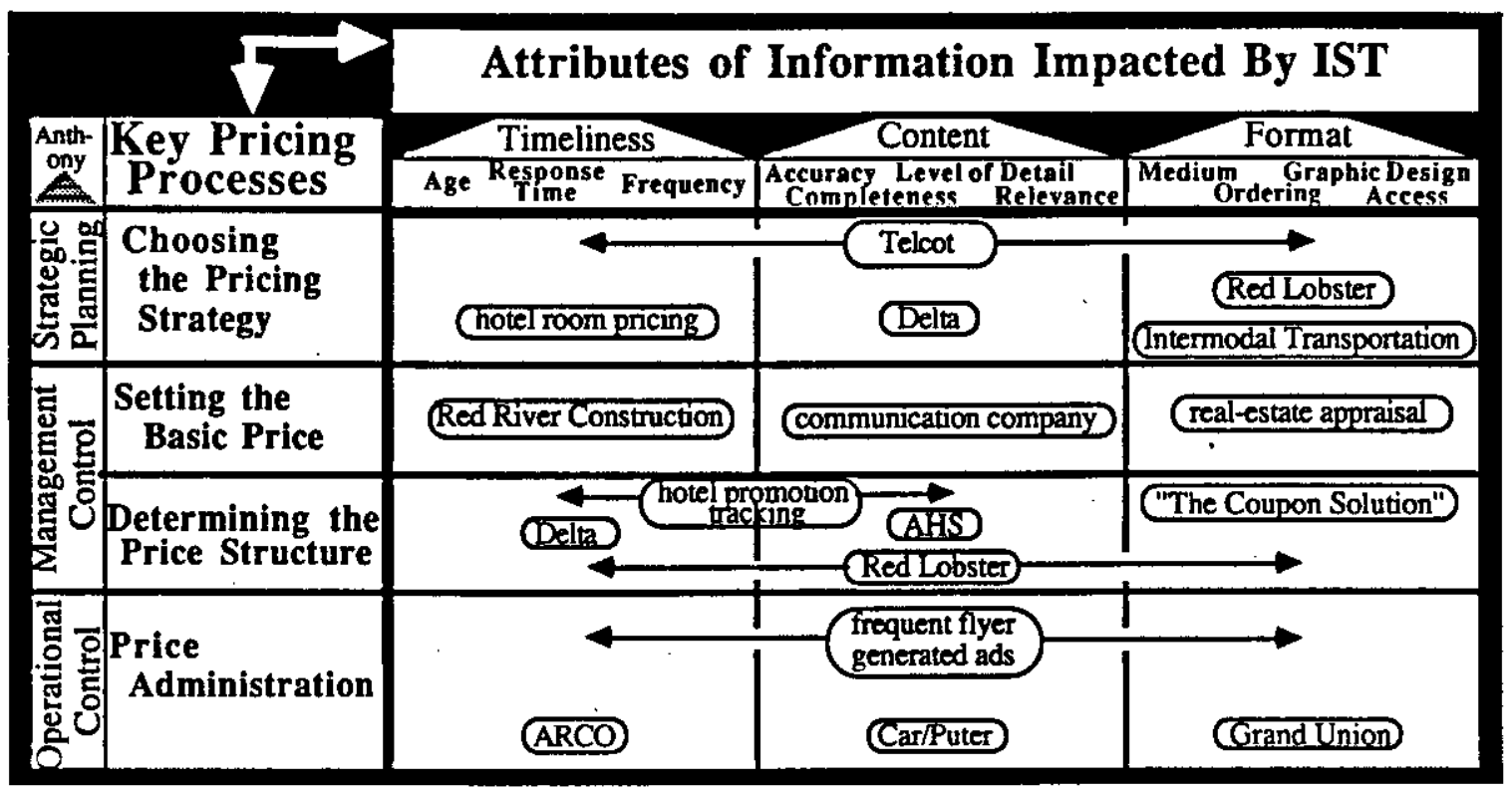

\section{Exhibit I}

Improving Information Characteristics for Key Pricing Processes 